\title{
Krzysztof Sypek*
}

\section{ZARZĄDZANIE STRATEGICZNE W POLSKICH PUBLICZNYCH SZKOŁACH MUZYCZNYCH}

\begin{abstract}
Z a r y s t r e ś c i: Artykuł prezentuje wyniki badania pilotażowego, dotyczącego zarządzania strategicznego w polskich publicznych szkołach muzycznych. Celem badania była identyfikacja oraz wskazanie praktyk w zakresie zarządzania strategicznego. Ramę koncepcyjną stanowiła Zrównoważona Karta Wyników. W pilotażu wykorzystano ankietę i pogłębiony wywiad niestandaryzowany. Artykuł wskazuje na potrzebę upowszechnienia wśród kadry kierowniczej szkół muzycznych możliwości wykorzystania Zrównoważonej Karty Wyników.
\end{abstract}

S ł o w a k 1 u c z o w e: zarządzanie strategiczne, zrównoważona karta wyników, publiczna szkoła muzyczna.

Klasyfikacja JEL: I25; L21

\section{WSTĘP}

Motywacją do pracy and artykułem było poszerzenie stanu wiedzy na temat wykorzystania zarządzania strategicznego oraz możliwości implementacji Zrównoważonej Karty Wyników w polskich publicznych szkołach muzycznych. Celem badania była identyfikacja, wskazanie praktyk w zakresie zarządzania strategicznego w badanych jednostkach.

Współczesne koncepcje zarządzania, zawierające w swych ramach zarządzanie strategiczne, oferują bogatą gamę sposobów, które mogą zdecydowanie pomóc w osiągnięciu lepszej sprawności organizacji pracy w szkołach muzycznych. Sprawność pod względem praktycznym określa się jako walory praktyczne zawierające: skuteczność, korzystność i ekonomiczność [Zieleniewski, 1969]. Skuteczność to działanie, które pozwala na osiągnięcie postawionych sobie celów. Korzystność to zdaniem J. Zieleniewskiego przewaga nabytków nad ubytkami (nabytki to na przykład cele a ubytki to zasoby, które zostały na

\footnotetext{
*Adres do korespondencji: Krzysztof Sypek, Uniwersytet Mikołaja Kopernika w Toruniu, Wydział Nauk Ekonomicznych i Zarządzania, Katedra Logistyki, ul. Gagarina 13 a, 87-100 Toruń, e-mail: krzysztofsypek@yahoo.com
} 
osiągnięcie tego celu przeznaczone). Ekonomiczność oznacza stosunek osiągniętego efektu do poniesionego nakładu w celu uzyskania tego efektu. Jeśli stosunek pomiędzy nabytkami a ubytkami jest większy od jeden, działanie można uznać za ekonomiczne. Sprawne zarządzanie organizacją, zgodnie z powyższymi walorami, możliwe jest poprzez stałą pracę nad doskonaleniem procesów zarządzania (w tym zarządzania strategicznego) w celu osiągnięcia doskonałości organizacyjnej.

\section{RYS HISTORYCZNY}

Współczesne koncepcje zarządzania, zawierające w swych ramach zarządzanie strategiczne, sięgają początków naukowego podejścia w teorii zarządzania, które wyłoniły się na przełomie XIX i XX wieku. Klasyczna szkoła zarządzania cechowała się mechanistycznym podejściem do organizacji, opartym na podziale pracy i hierarchizacji oraz próbami naukowego podejścia do wybranych elementów organizacji pracy. Szkołę tę reprezentowali H. Ford, F. W. Taylor, K. Adamiecki, M. Weber, H. Fayol. Szkoła zasobów ludzkich na piedestale stawia doskonalenie stosunków pracy, koncentruje się na pracowniku jako jednostce społecznej oraz sposobach jej motywowania. Szkoła ta swe początki zawdzięcza takim twórcom jak E. Mayo, A. Maslow, D. McGregor. Szkoła ilościowa ma swój początek w matematycznym i statystycznym wykorzystaniu walorów operacyjnych oraz w zakresie badań podczas II wojny światowej. Praktyczne zastosowanie statystyki doprowadziło do eksportu jej osiągnięć na sferę zarządzania w biznesie. Ze szkoły ilościowej wywodzą się późniejsze metody zarządzania operacyjnego, procesowego, czy omawiane bliżej w artykule zarządzanie strategiczne wraz z narzędziem służącym do jego komunikacji i monitorowania, czyli Zrównoważoną Kartą Wyników.

Zarządzanie strategiczne to proces informacyjno-decyzyjny (wspomagany funkcjami planowania, organizacji i kontroli), którego celem jest rozstrzyganie o kluczowych problemach działalności przedsiębiorstwa, o jego przetrwaniu i rozwoju ze szczególnym uwzględnieniem oddziaływań otoczenia i węzłowych czynników własnego potencjału wytwórczego [Łuczak, 2003]. W zarządzaniu strategicznym wyróżnia się najczęściej trzy procesy: przeprowadzenie analizy strategicznej, sformułowanie strategii oraz wprowadzenie jej w życie. Dążenie do poprawy procesów zarządzania strategicznego w szkołach muzycznych należy więc rozpocząć od przeprowadzenia analizy strategicznej. Wykorzystać można tu popularne narzędzie jakim jest analiza SWOT. Metoda ta wywodzi się ze szkoły planistycznej, która obok szkoły ewolucyjnej, szkoły prostych reguł oraz szkoły realnych opcji stanowi filar teorii zarządzania strategicznego. Kluczowe w procesie analizy jest określenie, czym jest doskonałość organizacyjna oraz jakie poziomy dojrzałości organizacyjnej możemy wyróżnić. Następnie należy 
ocenić stopień, na którym znajduje się szkoła, a także do jakiego poziomu może dążyć w kolejnych krokach doskonalenia. Pojęcie doskonałości organizacyjnej (ang. organizational excellence) pojawiło się w latach osiemdziesiątych XX wieku. Za sprawą T. Petersa i R. H. Watermana Jr. pojęcie to stało się podstawą dla wielu koncepcji, które uwypuklały kolejne etapy w ewolucji doskonałości biznesowej, takie jak: miękkie zasoby organizacji; zmiana; uczenie się; zintegrowany rozwój; budowanie jakości w ramach 4P; maksymalizowanie wartości dla interesariuszy; modele doskonałości biznesowej; dojrzałość systemu zarządzania. Ten ostatni etap, czyli dojrzałość systemu zarządzania, może być określony według pięciostopniowego modelu, dającego okazję do umiejscowienia swojego poziomu zaawansowania organizacyjnego podmiotu oraz określenia ścieżki do doskonalenia. Poziomy dojrzałości systemu zarządzania przedsiębiorstwem, które z powodzeniem można aplikować w organizacjach publicznych, takich jak publiczne szkoły muzyczne, przedstawia tabela 1 .

Tabela 1. Poziomy dojrzałości systemu zarządzania przedsiębiorstwem

\begin{tabular}{|c|c|}
\hline 1. Poziom początkowy & $\begin{array}{c}\text { Procesy biznesowe charakteryzowane są sporadycznie i często } \\
\text { chaotycznie. }\end{array}$ \\
\hline $\begin{array}{c}\text { 2. Podejście podstawowe - } \\
\text { powtarzalność procesów }\end{array}$ & $\begin{array}{c}\text { Została ustanowiona podstawowa kontrola realizacji procesów w celu } \\
\text { zarządzania ich wynikami, a także dyscyplina procesowa w celu uzy- } \\
\text { skania powtarzalności wcześniejszych wyników. }\end{array}$ \\
\hline $\begin{array}{c}\text { 3. Zdefiniowane podejście } \\
\text { systemowe }\end{array}$ & $\begin{array}{c}\text { Procesy biznesowe są dobrze zdefiniowane, zrozumiane i zintegrowa- } \\
\text { ne w jeden model systemowy odzwierciedlający sposób funkcjonowa- } \\
\text { nia, a więc łączący model przedsiębiorstwa i mapy procesów. }\end{array}$ \\
\hline $\begin{array}{c}\text { 4. Zarządzanie ciagłym dosko- } \\
\text { naleniem }\end{array}$ & $\begin{array}{c}\text { Procesy sa dobrze zintegrowane w obrębie całej organizacji, przy } \\
\text { jednoczesnym rozumieniu związów przyczynowo-skutkowych między } \\
\text { wynikami uzyskiwanymi w procesach, dostarczaną wartością i satysfak- } \\
\text { cją klienta. }\end{array}$ \\
\hline 5. Najlepszy w swojej klasie & $\begin{array}{c}\text { Ustanowiona została dobrze zaprojektowana metodyka zarządzania } \\
\text { doskonaleniem procesów, a przedsiębiorstwo zoptymalizowało swoją } \\
\text { strukturę organizacyjna, kulturę i systemy wokół nieustających zmian. } \\
\text { Przedsiębiorstwo wdrożyło skuteczny system zarządzania, generujący } \\
\text { stabilną poprawę wyników. }\end{array}$ \\
\hline
\end{tabular}

Źródło: Haffer R. (2011), Samoocena i Pomiar Wyników Działalności w Systemach Zarządzania Przedsiębiorstw, Wydawnictwo Naukowe Uniwersytetu Mikołaja Kopernika, Toruń.

Kolejnym etapem w zarządzaniu strategicznym jest sformułowanie strategii i następnie implementacja jej w organizacji. Formułowanie planu strategicznego to sformalizowany proces tworzenia długofalowej taktyki, ukierunkowanej na określenie i realizację celów organizacji [Stoner, Wankel, 1992]. Plan strategiczny i jego cele powinny być dla wszystkich zainteresowanych podmiotów zrozumiałe, mierzalne, określone w czasie, monitorowane przy pomocy sprawdzonych narzędzi zarządzania strategicznego. Zrównoważona Karta Wyników 
jest doskonałym przykładem, który można zastosować w procesach zarządzania strategicznego szkół muzycznych, poprzez możliwość określenia przejrzystych celów podzielonych na cztery perspektywy (formułowanie strategii) oraz monitorowanie ich realizacji (implementacja celów strategicznych) w codziennej działalności organizacji.

\section{ZRÓWNOWAŻONA KARTA WYNIKÓW - BALANCED SCORECARD (BSC)}

Najlepszym sposobem na zrozumienie istoty BSC jest zaczerpnięcie charakterystyki z opracowań jej twórców czyli Roberta S. Kaplana i Davida P. Nortona. Strategiczna karta wyników przekłada misję i strategię na cele oraz mierniki pogrupowane w czterech różnych perspektywach: finansowej, klienta, procesów wewnętrznych i rozwoju. Karta wyników to schemat, wspólny język używany do komunikowania misji i strategii firmy. Wykorzystuje ona mierniki, aby objaśniać pracownikom, jakie są czynniki wpływające na obecny i przyszły sukces firmy. W odróżnieniu od tradycyjnych systemów kontroli, karta wyników nie wymusza na pracownikach i jednostkach ścisłego trzymania się z góry ustalonego planu. Karta wyników jest bardziej systemem komunikowania, informowania i uczenia się, nie systemem kontroli [Kaplan, Norton, 2001]. Czy w istocie taka karta może zmienić na lepsze działanie szkół muzycznych? Badanie pilotażowe, które jest omówione poniżej, wskazało na duży potencjał do doskonalenia w sferze zarządzania strategicznego. Wykorzystanie BSC w praktyce placówek edukacyjnych jest już zauważalne w Polsce na wyższych uczelniach, dla potrzeb zarządzania strategicznego. Sięgając do publikacji Piotra Urbanka możemy dowiedzieć się, że uczelnie wyższe, ukazują wiele przypadków adaptacji tego modelu do uwarunkowań szkolnictwa wyższego poprzez modyfikację perspektyw oceny, dostosowującą je do specyfiki działalności uniwersytetów [Urbanek, 2017]. Opis zastosowania BSC w sektorze edukacji, jako narzędzia wspierającego zarządzanie jakością, możemy odnaleźć w artykule pary naukowców D., Karathanos i P. Karathanos. Autorzy przedstawili BSC w powiązaniu z nagrodą jakości przyznawaną w ramach The Baldrige National Quality Program. Pierwsze nagrody opracowane dla sektora edukacji zaprezentowane zostały w 2001 roku [Baldrige Education Awards] i objęły organizacje z regionów: Chugach School District, Pearl River School District, and University of Wisconsin-Stout [Karathanos, Karathanos, 2005].

Wykorzystanie BSC może dać początek bardziej holistycznemu, systemowemu spojrzeniu na zarządzanie w publicznych szkołach muzycznych ze szczególnym uwzględnieniem długoterminowego planowania, sposobów wprowadzenia go w życie, komunikowania zainteresowanym podmiotom i odnoszenia go do bieżących działań. W praktyce zarządzania szkołą badanie satysfakcji uczniów 
i rodziców (perspektywa klienta w BSC) powinno wejść do kanonu działań szkoły i w przyszłości stanowić drogowskaz działań zmierzających do dyskusji oraz doskonalenia szkolnictwa artystycznego w Polsce. W rozdziale czwartym przedstawiona została propozycja adaptacji BSC na potrzeby szkoły muzycznej.

\section{METODYKA BADAŃ}

\section{Opis badania}

Badanie pilotażowe przeprowadzone zostało w trzech publicznych szkołach muzycznych województwa kujawsko-pomorskiego. Dyrektorzy badanych placówek są nauczycielami pracującymi powyżej siedmiu lat w szkołach muzycznych, sprawującymi swoją kadencję po raz pierwszy. Ankietowani posiadają wykształcenie magisterskie zgodne $\mathrm{z}$ wymaganiami kwalifikacyjnymi dla pracowników pedagogicznych szkół muzycznych oraz do objęcia stanowiska dyrektora szkoły. Wybrane podmioty są publicznymi szkołami muzycznymi, których organem prowadzącym jest jednostka samorządu terytorialnego zgodnie z art. 4 punkt 16 Ustawy Prawo Oświatowe z dnia 14 grudnia 2016 r. Prawo Oświatowe. (Dz. U. z 2018 r. poz. 996, 1000 i 1290). Nadzór pedagogiczny nad tymi podmiotami prowadzi Ministerstwo Kultury i Dziedzictwa Narodowego poprzez specjalistyczny organ nadzoru pedagogicznego (Centrum Edukacji Artystycznej), realizujący między innymi programy mające pomóc kadrze kierowniczej szkoły w doskonaleniu jej działalności.

Badanie pilotażowe przeprowadzone zostało z wykorzystaniem badania ankietowego (Computer Assisted Web Interviews) i pogłębionego wywiadu niestandaryzowanego, zaliczanego do wywiadów swobodnych, którego celem jest zebranie danych bezpośrednio dotyczących osoby poddanej pomiarowi. Badanie miało charakter eksploracyjny i stanowi I etap badań realizowanych przez autora dla potrzeb opracowania dysertacji, która dotyczy zarządzania jakością w polskich szkołach muzycznych.

\section{Cel badania}

Celem badania była identyfikacja, wskazanie praktyk w zakresie zarządzania strategicznego w wybranych publicznych szkołach muzycznych w Polsce. Wyniki badań

Badania wskazały, jakie obszary zarządzania strategicznego (usystematyzowane na podstawie czterech perspektyw BSC) są stosowane w praktyce wybranych szkół i wyraźnie nakreśliły potrzebę doskonalenia tego obszaru zarządzania edukacją artystyczną. Strategia, koncepcja rozwoju szkoły przedstawiona przez dyrektora, to nic innego jak jedna z przewag konkurencyjnych, o które placówka powinna zabiegać pomimo tego, że nie funkcjonuje na gruncie tak zwanej drapieżnej walki o klienta w globalnym rynku. Stosowanie planów strategicznych w praktyce badanych podmiotów przedstawia tabela 2 . 
Tabela 2. Stosowanie planów strategicznych w badanych szkołach.

\begin{tabular}{|c|c|}
\hline Podmiot & Plany strategiczne \\
\hline Szkoła nr 1 & Tak \\
\hline Szkoła nr 2 & Nie \\
\hline Szkoła nr 3 & Tak \\
\hline
\end{tabular}

Źródło: Opracowanie własne na podstawie badania pilotażowego.

Dyrektorzy wskazali na posiadanie planu strategicznego $\mathrm{w}$ dwóch przypadkach. Brak takiego planu (szkoła nr 2), budzi duże wątpliwości na temat zrozumienia istoty strategii, która zapewne była przedstawiona podczas konkursu na stanowisko dyrektora w koncepcji pracy szkoły. Pojawia się tu pierwszy sygnał, który może prowadzić do wniosku implikującego stwierdzenie o niepełnym wykorzystaniu zalet planowania strategicznego w wybranych szkołach. Uwzględnienie w planach strategicznych zagadnień tylko połowy 2 z 4 perspektyw BSC wskazuje na duże możliwości doskonalenia tego obszaru zarządzania. Tabela 3 przedstawia występowanie w planach strategicznych aspektów zarządzania pogrupowanych wg metody BSC w szkołach, które wskazały na wykorzystywanie w swej pracy planowania długoterminowego.

Tabela 3. Uwzględnienie czterech perspektyw BSC w planowaniu strategicznym

\begin{tabular}{|c|c|c|}
\hline Perspektywa dotycząca & Szkoła nr 1 & Szkoła nr 3 \\
\hline Finansów & Tak & Nie \\
\hline Klientów & Nie & Nie \\
\hline Procesów wewnętrznych & Nie & Tak \\
\hline Rozwoju & Tak & Tak \\
\hline
\end{tabular}

Źródło: Opracowanie własne na podstawie badania pilotażowego.

Ciekawą konkluzją wynikającą z analizy tej części pytań jest to, że żadna ze szkół nie wskazała perspektywy klientów, jako czynnika uwzględniającego planowanie strategiczne w swoich szkołach. Potwierdza się tu niestety praktyka, w której analiza procesów edukacyjnych z perspektywy odbiorcy usług edukacyjnych ogranicza się do bieżącego rozwiązywania skarg i wniosków niezadowolonych uczniów i rodziców. Długoterminowe planowanie badania zadowolenia i lojalności uczniów, rodziców a także klientów wewnętrznych, jakimi są pracownicy szkoły, wkracza powoli do praktyki zarządczej w szkolnictwie artystycznym. Badania zadowolenia, lojalności i oczekiwań klientów (wewnętrznych i zewnętrznych) powinny być fundamentalną częścią systemu zarządzania jakością w szkołach muzycznych.

W badaniu pilotażowym umieszczono również pytania dotyczące barier i najpilniejszych potrzeb, które mogłyby usprawnić zarządzanie szkołą muzyczną w codziennej pracy kadry kierowniczej. Badani wskazali na takie bariery jak: przejrzystość aktów prawnych regulujących prace szkoły; brak szkoleń dla 
kadry kierowniczej z zakresu zarządzania; zmiany w przepisach o kwalifikacjach nauczycieli; brak swobody działanie dyrektora szkoły. Wyniki badania potwierdziły potrzebę zwiększenia świadomości kadry zarządzającej na temat współczesnych koncepcji zarządzania. Badanie przeprowadzone na potrzeby tego artykułu, miało za zadanie wstępnie zdiagnozować problem zarządzania jakością w szkołach muzycznych, ze szczególnym uwzględnieniem zarządzania strategicznego.

\section{WNIOSKI I REKMENDACJE}

Wnioskiem i rekomendacją, jaka nasuwa się po charakterystyce powyższych wyników badań, jest konieczność rozpoczęcia prac wspierających kadrę zarządzającą szkół muzycznych w stworzeniu kompleksowego systemu wspomagającego zarządzanie strategiczne, który uwzględniać będzie wszystkie perspektywy i funkcje zarządzania. Okresowa samoocena, jako całościowe ujęcie wszystkich perspektyw w zarządzaniu szkołą oraz dokonywanie pomiarów podczas realizacji planów strategicznych, to podstawa ewolucji zarządzania, która ma miejsce w krajach rozwiniętych. Polskie szkolnictwo artystyczne, aby nie stracić swojej dobrej pozycji, musi nadrobić pewne zaległości w kompleksowym podejściu do zarządzania. Propozycją, która może pomóc w doskonaleniu procesów zarządzania, jest zastosowanie Zrównoważonej Karty Wyników opracowanej na potrzeby szkoły muzycznej przedstawionej w tabeli 5 .

Specyfika publicznych szkół muzycznych (szczególnie bez pionu ogólnokształcącego) charakteryzuje się tym, że uczniowie czyli bezpośredni klienci szkoły, nie trafiają do niej w wyniku powszechnego obowiązku szkolnego, lecz z własnej chęci pogłębienia wiedzy i umiejętności muzycznych oraz obcowania z tzw. kulturą wysoką. Powstanie w Polsce wielu nowych szkół muzycznych, doprowadziło do sytuacji nieznanej wcześniej w tej branży, tj. do wymiany informacji wśród uczniów, rodziców o jakości kształcenia, warunkach lokalowych, materiałowych, rozwoju szkoły. Konsekwencją tego kiełkującego zróżnicowania jakości, są pojawiające się migracje zaawansowanych uczniów do szkół i nauczycieli, którzy cieszą się lepszą opinią (w potocznym rozumieniu lepszą jakością) w środowisku muzycznym. Kryterium odległości od miejsca zamieszkania przestaje być barierą $\mathrm{w}$ wyborze pomiędzy dostępnymi szkołami. Jasnym jest, że zastosowanie jednej ze współczesnych koncepcji zarządzania stosowanych w biznesie, może przynieść korzyści również takiej instytucji non profit, jaką jest szkoła. 
Tabela 5. Zrównoważona Karta Wyników-opracowana dla publicznej szkoły muzycznej

\begin{tabular}{|c|c|c|}
\hline $\begin{array}{l}\text { Perspek- } \\
\text { tywa }\end{array}$ & Przykład celu strategicznego & Miernik \\
\hline \multirow[t]{4}{*}{$\begin{array}{l}\text { Finanso- } \\
\text { wa }\end{array}$} & $\begin{array}{l}\text { Wydatkowanie zgodne z planem bu- } \\
\text { dżetowym }\end{array}$ & Suma wydatków \\
\hline & $\begin{array}{l}\text { Udział w programach, konkursach, } \\
\text { europejskich, krajowych, regionalnych } \\
\text { finansujących edukację i kulturę }\end{array}$ & $\begin{array}{c}\text { Liczba projektów w których szkoła aplikowała } \\
\text { o dofinansowanie/liczba projektów, w których } \\
\text { szkoła otrzymała dofinansowanie }\end{array}$ \\
\hline & $\begin{array}{c}\text { Terminowe i prawidłowe prowadzenie } \\
\text { procesów finansowych }\end{array}$ & Liczba płatności regulowanych w terminie. \\
\hline & $\begin{array}{l}\text { Obniżenie kosztów utrzymania budyn- } \\
\text { ków, administracyjnych, itp. }\end{array}$ & $\begin{array}{l}\text { Ograniczenie kosztów eksploatacji budynków, ko- } \\
\text {-sztów materiałów eksploatacyjnych, biurowych itp. }\end{array}$ \\
\hline \multirow[t]{3}{*}{ Klienta } & $\begin{array}{c}\text { Rosnaca satysfakcja klientów we- } \\
\text { wnętrznych (pracownicy szkoły) } \\
\text { i zewnętrznych(uczniowie, rodzice, } \\
\text { organ prowadzący i nadzoru pedago- } \\
\text { gicznego, kontrahenci współpracujący } \\
\text { ze szkoła) }\end{array}$ & $\begin{array}{c}\text { Wskaźnik zadowolenia, poniżej którego wdraża- } \\
\text { na jest procedura dodatkowej obserwacji pracy } \\
\text { nauczyciela lub dodatkowego wynagradzania } \\
\text { nauczycieli. }\end{array}$ \\
\hline & Lojalność klientów/uczniów. & $\begin{array}{l}\text { Wskaźnik rezygnacji uczniów u poszczególnych } \\
\text { nauczycieli }\end{array}$ \\
\hline & Zwiększenie liczby uczniów szkoły & $\begin{array}{c}\text { Zwiększenie liczby kandydatów przystępujących } \\
\text { do procesu rekrutacji }\end{array}$ \\
\hline \multirow{4}{*}{$\begin{array}{l}\text { Proce- } \\
\text { sów we- } \\
\text { wnętrz- } \\
\text { nych }\end{array}$} & Doskonalenie procesów edukacyjnych & $\begin{array}{l}\text { Wzrost średniej ocen podczas egzaminów i prze- } \\
\text { słuchań CEA }\end{array}$ \\
\hline & & $\begin{array}{l}\text { Potwierdzenie przeprowadzenia nadzoru pedago- } \\
\text { gicznego oraz ewaluacji wewnętrznej }\end{array}$ \\
\hline & $\begin{array}{l}\text { Kreowanie wartości przyciagających } \\
\text { nowych uczniów }\end{array}$ & $\begin{array}{c}\text { Liczba tworzonych nowych kierunków lub uczniów } \\
\text { przyjętych na zajęcia tworzone z inicjatywy na- } \\
\text { uczycieli bądź w wyniku potrzeb ujawnionych } \\
\text { podczas badania satysfakcji }\end{array}$ \\
\hline & $\begin{array}{l}\text { Doskonalenie systemu zarządzania } \\
\text { jakością }\end{array}$ & $\begin{array}{c}\text { Liczba nauczycieli biorących udział w pracach } \\
\text { zespołu ds. zarządzania jakością }\end{array}$ \\
\hline \multirow[t]{3}{*}{ Rozwoju } & $\begin{array}{c}\text { Określenie potrzeb materialnych } \\
\text { i kadrowych niezbędnych do rozwoju } \\
\text { szkoły }\end{array}$ & $\begin{array}{l}\text { Procesy inwestycyjne. Liczba zakupionych instru- } \\
\text { mentów i akcesoriów muzycznych, biurowych, itp. }\end{array}$ \\
\hline & $\begin{array}{l}\text { Poznanie nowoczesnych form edukacji } \\
\text { muzycznej, zarządzania, wykorzysta- } \\
\text { nia narzędzi multimedialnych w proce- } \\
\text { sach edukacji i wychowania }\end{array}$ & $\begin{array}{c}\text { Liczba pracowników bioracych udział w szkole- } \\
\text { niach, liczba pracowników biorących udział } \\
\text { w tworzeniu nowych inicjatyw kulturalnych i edu- } \\
\text { kacyjnych }\end{array}$ \\
\hline & $\begin{array}{l}\text { Bieżąca analiza aktów prawnych (oraz } \\
\text { ich projektów) dotyczących oświaty }\end{array}$ & $\begin{array}{l}\text { Liczba pracowników bioraca udział w analizie, licz- } \\
\text { ba przeanalizowanych projektów aktów prawnych } \\
\text { i ewentualnych wniosków związanych z konsulta- } \\
\text { cjami społecznymi projektów aktów prawnych }\end{array}$ \\
\hline
\end{tabular}

Źródło: Kaplan R. S., Norton D. P. (2001), Strategiczna karta wyników Jak przełożyć strategię na działanie, Wydawnictwo Naukowe PWN, Warszawa. 
Rozważane w tym artykule zarządzanie strategiczne wykorzystane do doskonalenia procesów w szkole, może stanowić jedną z przewag konkurencyjnych, która będzie mogła decydować o jej sukcesie (coraz większa liczba zadowolonych uczniów), bądź porażce na rynku edukacyjnym (coraz częstsze rezygnacje lub w najbardziej czarnym scenariuszu zamknięcie szkoły). Ciekawe ujęcie sukcesu zostało wskazane w publikacji opisującej systemy zarządzania jakością w ujęciu przewag konkurencyjnych. Sukces jest wynikiem skutecznej realizacji założonych celów strategicznych, która jest możliwa dzięki zastosowaniu unikatowej strategii, kreującej wyższą w oczach klientów wartość oferty rynkowej w stosunku do wartości dostarczanej na rynek przez konkurentów [Haffer, 2003]. Prostym przepisem na ten sukces jest wprowadzenie w pierwszej kolejności Zrównoważonej Karty Wyników, która pomoże opracować bądź skorygować strategię (uwzględniającą ważną perspektywę klienta) i poprawi w szybki oraz stosunkowo tani sposób zarządzanie szkołą. Kolejnym naturalnym etapem mogłoby być zapoznanie dyrektorów szkół muzycznych z zaletami stosowania okresowej samooceny procesów zarządzania według Wspólnej Metody Oceny-CAF. Współczesne metody i narzędzia zarządzania, powinny być wprowadzane przy pomocy ważnego czynnika, którym jest pozytywne nastawienie pracowników do planowanych zmian, co związane jest z dużym nakładem pracy w postaci informowania o rezultatach, jakie można dzięki tym zmianom osiągnąć. Aldona Glińska-Neweś i Rafał Haffer w swojej publikacji wskazują i udowadniają tezę, że pobudzanie pozytywnego potencjału w przedsiębiorstwie stanowi czynnik dynamizujący jego sukces [Haffer, Glińska-Neweś, 2013]. Starannie przygotowany proces wprowadzania nowej kultury zarządzania szkołami muzycznymi (wykorzystujący BSC) może przyczynić się istotnie do polepszenia oferty edukacyjnej polskich publicznych szkół muzycznych.

Wyniki badania pilotażowego ujawniły potrzebę szczegółowego zajęcia się problematyką zarządzania strategicznego w publicznych szkołach muzycznych. Wskazały też pewną lukę, którą warto uzupełnić pracami naukowymi dotyczącymi potrzeb i barier, z którymi boryka się kadra kierownicza w procesach zarządzania szkołami muzycznymi. Jedną ze wskazanych przez badanych potrzeb było szkolenie z zakresu zarządzania dla kadry kierowniczej. Zdaniem autora, szkolenia, studia podyplomowe, bądź inne formy pogłębienia podstawowej wiedzy o współczesnych koncepcjach zarządzania, powinny być obowiązkowe już na etapie pracy nauczyciela lub idąc szerzej, na etapie studiów przygotowujących do pracy nauczyciela. Kadra kierownicza szkół to nauczyciele tych jednostek, którzy często wiedzę z zakresu zarządzania czerpią wyłącznie z doświadczenia. Usystematyzowanie podstawowej wiedzy w zakresie nauk o organizacji i zarządzaniu, poszerzyłoby ilość kadry odpowiednio przygotowanej do pełnienia funkcji kierowniczych. 


\section{PODSUMOWANIE}

Reasumując rozważania niniejszej publikacji, należy wskazać na potrzebę rozpoczęcia prac pozwalających kadrze kierowniczej osiągnąć kolejny, wyższy poziom zarządzania szkołami muzycznymi. Dzięki aktywnej pomocy szkoleniowej z zakresu nauk o zarządzaniu i wykorzystaniu współczesnych koncepcji zarządzania, będzie to możliwe w niedługim czasie, przy stosunkowo niedużych nakładach finansowych. Możliwość prowadzenia szkoleń z zakresu zarządzania organizacjami, mogłoby wejść na stałe do repertuaru szkoleń Centrum Edukacji Artystycznej oraz jako przedmiot na uczelniach wyższych, przygotowujących pedagogów szkół muzycznych. Przedstawione wyniki badania pilotażowego wskazują, że w polskich publicznych szkołach muzycznych brakuje jeszcze pomysłu na ujednolicone, przejrzyste sposoby zarządzania organizacją, które są dobrane do specyfiki tych podmiotów. Rozważania przedstawione w tej publikacji mogą również z powodzeniem odnieść się do próby doskonalenia procesów zarządzania strategicznego w każdym typie szkoły. Należy również zdaniem autora przyjrzeć się bardziej szczegółowo celom strategicznym w odniesieniu do różnych form zatrudnienia nauczycieli w szkołach. Brian Fidler swojej publikacji dotyczącej zarządzania strategicznego w szkołach zaznacza, że każda strategia powinna brać pod uwagę potrzeby pracowników obecnie zatrudnionych, jak i tych, którzy potencjalnie będą musieli być zatrudnieni. Strategia ta musi implikować rozwój obecnych pracowników oraz tych, którzy będą wymagani w niedalekiej przyszłości [Fidler, 2002]. B. Fidler zaznacza, że w przypadku szkoły strategia obejmująca tych pracowników powinna być na tyle szeroka i szczegółowa, aby sprostać potrzebom nie tylko pracowników pedagogicznych, ale również administracji, obsługi technicznej (w szczególności obsługi informatycznej, ochrony danych, itp.), czy kadry kierowniczej. Te uwagi mają szczególne znaczenie, zdaniem autora artykułu, ze względu na szybki postęp technologiczny i rozwój narzędzi wspomagających, jak i zastępujących nauczanie stacjonarne. Spojrzenie w przyszłość i poszerzenie oferty edukacyjnej szkoły muzycznej o coraz bardziej popularne nauczanie na odległość, może być już w niedalekiej przyszłości nie tylko dodatkowym atutem, ale może stać się wręcz niezbędne w strategii zarządzania, która pozwoli utrzymać się na rynku usług edukacyjnych.

Współczesne koncepcje zarządzania, w tym zarządzania strategicznego wkraczają szeroko na pole administracji publicznej oraz edukacji w Europie zachodniej oraz w Polsce. Posiadają one duży potencjał czekający na wykorzystanie w polskich publicznych szkołach muzycznych.

\section{LITERATURA}

Fidler B., (2002), Strategic Management for School Development Leading your School's Improvement Strategy, Paul Chapman Publishing, London 
Haffer R., (2011), Samoocena i Pomiar Wyników Działalności w Systemach Zarządzania Przedsiębiorstw, Wydawnictwo Naukowe Uniwersytetu Mikołaja Kopernika, Toruń.

Haffer R., Glińska-Neweś A., (2013), Pozytywny Potencjał Organizacji jako determinanta sukcesu przedsiębiorstwa. Przypadek Polski i Francji, „Zarządzanie i Finanse”, vol. 4, nr 1, Gdańsk.

Kaplan R. S., Norton D. P., (2001), Strategiczna karta wyników Jak przełożyć strategię na działanie, Wydawnictwo Naukowe PWN, Warszawa.

Karathanos D., Karathanos P., (2005), Applying the Balanced Scorecard to Education, Journal of Education for Business, Volume 80 Issue 4, [online], https://www.tandfonline.com/doi/ abs/10.3200/JOEB.80.4.222-230, [18.02.2019].

Łuczak M., (2003), Strategie w działalności przedsiębiorstwa Wyższa Szkoła Ekonomiczna, Warszawa.

Stoner J., Wankel C., (1992), Kierowanie, PWE, Warszawa.

Urbanek P., (2017), Zrównoważona karta wyników w procesie zarzadzania uczelnia publiczna, Dylematy zarządzania kosztami i dokonaniami, „Prace Naukowe Uniwersytetu Ekonomicznego we Wrocławiu" nr 472.

Zieleniewski J. (1969), Organizacja i zarządzanie, Polskie Wydawnictwo Naukowe, Warszawa.

\section{THE STRATEGIC MANAGEMENT IN POLISH PUBLIC SCHOOLS OF MUSIC}

A b s t r a c t: The article presents the results of a pilot study on strategic management in Polish public music schools. The aim of the study was to identify and identify practices in the field of strategic management. The conceptual framework was the Balanced Scorecard. The pilot used a questionnaire and in-depth non-standardized interview. The article points out the need to popularize among the managers of music schools the possibility of using the Balanced Scorecard.

K e y w o r d s: strategic management, balanced scorecard, public music school. 
